$\xi=$

\title{
Mathematical computation of water quality index to determine surface water quality of manyad storage tank, Aurangabad district, Maharashtra, India
}

\author{
M. L. Dhumal * \\ Department of Mathematics, Deogiri College, Station road, Aurangabad-431005, Maharashtra, India \\ *Corresponding author E-mail: mldhumal19@gmail.com
}

\begin{abstract}
The present work aims to assess the water quality index (WQI) of Manyad Storage tank, of Aurangabad district, Maharashtra, India. The surface water sample were assessed for physico-chemical parameters namely pH, Electrical Conductivity, Total Dissolved Solid, Total Hardness, Bicarbonate, Chlorides, Sulphates, Nitrates, Calcium, Magnesium, Sodium, Potassium and Fluoride in post-monsoon season of 2020. For calculating the water quality index (WQI), thirteen parameters namely, pH, electrical conductivity, total dissolved solids, total hardness, bicarbonate, calcium, magnesium, sodium, potassium, chloride, sulphate, nitrate and fluorides were considered. Weighted arithmetic water quality index method was used to find surface water quality index (WQI). The water quality index of surface water found to be 96.24 indicating poor water category, which shows that whole water from the Manyad Storage tank is of very poor quality and treatment must be given before use for drinking purpose.
\end{abstract}

Keywords: Water Quality Parameters; Water Quality Index; Manyad Storage Tank; Parala; Maharashtra.

\section{Introduction}

Water covers $71 \%$ of the Earth's surface and is vital for all known forms of life. Clean, safe and adequate freshwater is vital to the survival of all living organisms and the functioning of eco systems, communities and economies. The quality of the world's water is increasingly threatened as human populations grow, industrial and agricultural activities expand, and as climate change threatens to change the global hydrologic cycle. Due to rapid growth of population, urbanization, industrialization, and agriculture activities, all water resources are under stress (UN-Water, 2010; Aher, 2017; Aher and Dhumal, 2017). Water quality refers to the chemical, physical and biological characteristics of water (CIA, 2014; Diersing and Nancy, 2009; Boah, et al,2015). The quality of surface water in an inland water bodies have a profound effect on the ground water table and ground water quality of the nearby aquifers due to existence of direct interaction between surface and ground water. surface water quality depends not only on natural processes such as precipitation inputs, erosion, and weathering of crustal material, etc. but also on anthropogenic influences such as urban, industrial, and agricultural activities (Papatheodorou et al. 2006; Ravikumar, et al, 2013).

The rainfall is most important hydrometeorological factor that plays a very significant role in their charge of surface as well as groundwater system. Rainfall is a usually followed expression for the liquid form of precipitation, which contributes in solving the problems related with water bodies like dams, tanks, lakes as well as reservoirs (Dangi et al, 2018; Dhumal and Aher,2019). Water quality is mostly affected by geochemical characteristics, dissolved ion content, climate, lithology, mineral weathering, geochemical reactions, solubility of salts, dissolution/precipitation reactions, ion exchange, wet and dry deposition of atmospheric salt and by various anthropogenic activities (Jiang and Yan, 2010; Zhang et al.,2012; Varade et al.,2014; Bozdag and Gocmez,2013; Sheikhy , et al., 2014; Sridharan, and Nathan, 2017; Wagh et al., 2018; Aher et al, 2019). The water quality index (WQI) summarizes large amounts of water quality data into simple terms such as excellent, good, bad, etc. for reporting to managers and the public in a consistent manner (Boyacioglu,2010). The indices are among the most effective ways to communicate the information on water quality trends for the water quality management (Jagadeeswari and Ramesh, 2012). WQI is valuable and unique rating to depict the overall water quality status in a single term that is helpful for the selection of appropriate treatment technique to meet the concerned issues (Tyagi et al.2013; Shah, and Joshi,2017). The assessment of drinking water quality using water quality index (WQI) is one of the best tools which was developed in the 1970s by the Oregon Department of Environmental Quality to summarize and assessing the status of water quality (Brown et al., 1972; Tiwari and Mishra 1985; Singh 1992; Mishra and Patel 2001; Naik and Purohit 2001; Chaterjee, and Raziuddin, 2002; Yogendra and Puttaiah, 2008; Alobaidy et al., 2010; Latha and Rao, 2010; Ketata et al., 2012; Tyagi et al., 2013; Li, 2016; Krishan et al., 2016; Aher, and Gaikwad, 2017; Bidhuri, and Khan, 2020; Deshpande et al., 2020; Aher, et al, 2020; Aher et al, 2020a ). Water quality index (WQI) is one of the most effective tools to communicate information on the quality of water to the concerned citizens and policy makers as it is an important parameter for the assessment and management of surface/ground waters. Hence, the present work has been carried out to know the water 
quality index (WQI) of the surface water of Manyad Storage tank, Aurangabad district, Maharashtra, India. The Manyad storage tank is an earthen embankment type dam. It is situated on Manyad river near village Parala in Vaijapar block of Aurangabad district. The Manyad storage tank which was built in 2003 serves as the major source of water for nearby villages and having capacity of 6.11 thousand cubic meters out of which 5.38 thousand cubic meters is live storage. The Manyad water irrigate near about 880 hector land of surrounded area of Manyad valley. All water is reserve for only irrigation purpose however same nearby village having drinking water supply scheme from this storage tank. Geologically study area is covered by the deccan trap lava flows of upper Cretaceous to lower Eocene age and the basaltic lava flows belonging to the deccan trap is the only major geological formation (Aher and Deshpande, 2011; Deshpande and Aher, 2012).

\section{Materials and methods}

The surface water samples collected from the Manyad storage tank in a one litre pre-cleaned polyethylene bottles in post-monsoon season of 2020. The physicochemical analyses encompassing estimation of major cations calcium magnesium, sodium and potassium anions bicarbonate, chloride, sulphate, nitrate and fluoride besides general parameters such as $\mathrm{pH}$, electrical conductivity, total dissolved solid and total hardness. In situ parameters like $\mathrm{pH}$, electrical conductivity, total dissolved solid was measured immediately in the field immediately after sampling. The standard analytical procedures as recommended by the APHA (2012) were employed in the present study. The hydrogen ion concentration ( $\mathrm{pH}$ ), Electrical conductivity (EC) and total dissolved solids (TDS) were measured using digital portable meters. Calcium, magnesium bicarbonate and chloride were analysed by volumetric titration methods, sodium and potassium were measured using the flame photometer, sulphate, nitrate and fluoride were determined by spectrophotometric technique. The WQI provides a comprehensive picture of the quality of surface/ground water for most domestic uses. WQI is defined as a rating that reflects the composite influence of different water quality parameters (Sahu and Sikdar 2008). WQI is calculated from the point of view of the suitability of surface and/or groundwater for human consumption. Hence, for calculating the WQI in the present study, 13 parameters namely, $\mathrm{pH}$, electrical conductivity, total dissolved solids, total hardness, bicarbonate, calcium, magnesium, sodium, potassium, chloride, sulphate, nitrate and fluorides have been considered.

There were three steps for computing WQI of a water sample (US EPA 2009):

1) obtain measurements on individual water quality indicators

2) transform measurements into subindex values to represent them on a common scale

3) aggregate the individual subindex values into an overall WQI value.

Horton (1965) used the arithmetic aggregation function for the WQI. Brown et al. (1970) also employed basic arithmetic weighting, although without the multiplicative variables. The calculation of WQI using Weighed Arithmetic Index method after Brown et al. (1972) was used which involve the following steps:

Step 1. Calculation of unit weight $\left(\mathrm{W}_{\mathrm{n}}\right)$ factors for each parameter by using the formula

$\mathrm{W}_{\mathrm{n}}=\frac{\mathrm{k}}{\mathrm{S}_{\mathrm{n}}}$

Where,

$\mathrm{K}=\frac{1}{1 / \mathrm{S}_{1}+1 / \mathrm{S}_{2}+1 / \mathrm{S}_{3}+\ldots \ldots+{ }^{1} / \mathrm{Sn}}=\frac{1}{\sum \frac{1}{\mathrm{~S}_{\mathrm{n}}}}$

$S_{n}=$ standard desirable value for $n^{\text {th }}$ parameter

On summation of all selected parameters unit weight factor, $\mathrm{W}_{\mathrm{n}}=1$ (unity)

Step 2. Calculate the sub-index $\left(\mathrm{q}_{\mathrm{n}}\right)$ value by using formula

$\mathrm{q}_{\mathrm{n}}=\frac{\mathrm{v}_{\mathrm{n}}-\mathrm{V}_{\mathrm{o}}}{\mathrm{s}_{\mathrm{n}}-\mathrm{v}_{\mathrm{o}}} \times 100$

$\mathrm{V}_{\mathrm{n}}$ is the mean concentration of the nth parameter,

$\mathrm{S}_{\mathrm{n}}$ is the standard desirable value of the nth parameter

$\mathrm{V}_{\mathrm{o}}$ are actual values of the parameter in pure water, generally $\mathrm{V}_{\mathrm{o}}=0$, for most parameters except $\mathrm{pH}$

For $\mathrm{pH}$, the ideal value is 7.0 because of pure water and a permissible value is 8.5 .

So, the calculation of quality rating for $\mathrm{pH}$ is calculated from the following equation:

$\mathrm{q}_{\mathrm{pH}}=\frac{\mathrm{v}_{\mathrm{pH}}-7}{8.5-7} \times 100$

Where $\mathrm{VpH}=$ observed value of $\mathrm{pH}$.

Step 3. Combining step 1 and step 2 WQI is calculated by the following equation.

$\mathrm{WQI}=\sum_{\mathrm{n}=1}^{\mathrm{n}} \mathrm{q}_{\mathrm{n}} \mathrm{w}_{\mathrm{n}} / \sum_{\mathrm{n}=1}^{\mathrm{n}} \mathrm{w}_{\mathrm{n}}$

Water quality index (WQI) was computed to evaluate the groundwater suitability for drinking purposes. For computing WQI, the above three steps are involved in WQI calculation, the computed WQI values are than categorized into five classes, excellent, good, poor, very poor and unsuitable for drinking purposes. The table 1 shows classification of water quality, based on its water quality index values.

Table 2: Classification of Water Quality, Based on Its Quality Index

\begin{tabular}{lll}
\hline Sr. No. & WQI Values & Water type \\
\hline 1 & $0-25$ & Excellent \\
2 & $26-50$ & Good water \\
3 & $51-75$ & Poor water \\
4 & $76-100$ & Very poor water \\
\hline
\end{tabular}




$5 \quad>100 \quad$ Unsuitable

Table 2: Calculation of Surface Water Quality Index (WQI) of Manyad Storage Tank

\begin{tabular}{|c|c|c|c|c|c|c|c|c|c|c|}
\hline Parameter & Standards Values $\left(S_{n}\right)$ & $1 / S_{n}$ & $\sum 1 / S_{n}$ & $\left.\mathrm{~K}=1 / \sum 1 / \mathrm{S}_{\mathrm{n}}\right)$ & $\mathrm{W}_{\mathrm{n}}=\mathrm{K} / \mathrm{S}_{\mathrm{n}}$ & $\mathrm{V}_{\mathrm{o}}$ & $V_{n}$ & $V_{n} / S_{n}$ & $Q_{n}=V_{n} / S_{n} \times 100$ & $\mathrm{~W}_{\mathrm{n}} \mathrm{Q}_{\mathrm{n}}$ \\
\hline $\mathrm{pH}$ & 8.5 & 0.118 & 1.296 & 0.7717 & 0.0908 & 7 & 7.96 & 0.64 & 64 & 5.810 \\
\hline TDS & 500 & 0.002 & 1.296 & 0.7717 & 0.0015 & 0 & 937.5 & 1.875 & 187.5 & 0.289 \\
\hline $\mathrm{TH}$ & 200 & 0.005 & 1.296 & 0.7717 & 0.0039 & 0 & 560 & 2.8 & 280 & 1.080 \\
\hline $\mathrm{Cl}$ & 250 & 0.004 & 1.296 & 0.7717 & 0.0031 & 0 & 180 & 0.72 & 72 & 0.222 \\
\hline $\mathrm{SO} 4$ & 200 & 0.005 & 1.296 & 0.7717 & 0.0039 & 0 & 58 & 0.29 & 29 & 0.112 \\
\hline NO3 & 45 & 0.022 & 1.296 & 0.7717 & 0.0171 & 0 & 47 & 1.044 & 104.44 & 1.791 \\
\hline $\mathrm{F}$ & 1 & 1 & 1.296 & 0.7717 & 0.7717 & 0 & 1.01 & 1.01 & 101 & 77.940 \\
\hline $\mathrm{Mg}$ & 30 & 0.033 & 1.296 & 0.7717 & 0.0257 & 0 & 79.7 & 2.657 & 265.67 & 6.834 \\
\hline $\mathrm{Na}$ & 200 & 0.005 & 1.296 & 0.7717 & 0.0039 & 0 & 51 & 0.255 & 25.5 & 0.098 \\
\hline $\mathrm{K}$ & 12 & 0.083 & 1.296 & 0.7717 & 0.0643 & 0 & 0.1 & 0.0083 & 0.8333 & 0.054 \\
\hline
\end{tabular}

\section{Discussion}

Application of water quality index (WQI) is a useful method in assessing the suitability of water for various beneficial uses. Water quality index was computed to evaluate the groundwater suitability for drinking purposes. It improves understanding of water quality issues by integrating complex data and generating a score that describes water quality status and evaluates water quality trends (Boyacioglu, 2007; Aher et al, 2020). The surface water quality index has been classified into (i) Excellent water (WQI <25), (ii) Good water (WQI 26 - 50), (iii) Poor water (WQI 51 - 75), (iv) Very poor water (WQI 76 - 100) and (v) Unsuitable for drinking purpose (WQI >100) (Table 1). The table 2 gives the mean concentration values $\left(V_{n}\right)$ of the twelve selected physico-chemical parameters of water samples collected in a post-monsoon season of 2020 , standard drinking water values $\left(\mathrm{S}_{\mathrm{n}}\right)$ according to World Health Organisation (WHO, 2011) and Bureau of Indian Standards (BIS, 2012), unit weights $\left(W_{n}\right)$, water quality rating $\left(Q_{n}\right)$ and $W_{n} Q_{n}$. The water quality index (WQI) of the Manyad Storage tank was then calculated using the weighted arithmetic index formula as follows:

WQI $=\frac{\sum_{n=1}^{n} q_{n} w_{n}}{\sum_{n=1}^{n} w_{n}}=\frac{94.24}{1}=94.24$

Based on the water quality index, this value (94.24) falls within 76-100 of the classification indicating very poor category for drinking purpose and must therefore be treated before use.

\section{Conclusion}

Water quality index technique used to assess the suitability of surface water Manyad Storage tank for drinking purposes illustrated that Manyad Storage tank water belongs to very poor water category for drinking purpose. The high-water quality index (WQI) values are mainly due to the presence of higher concentration of total dissolved solids, electrical conductivity, bicarbonate, nitrate, total hardness, calcium and magnesium in the surface water, therefore, the analysis revealed that the surface water of Manyad Storage tank needs some degree of treatment before usage for drinking purpose.

\section{Acknowledgement}

The author is thankful to Principal, Deogiri College, Aurangabad, Director, Institute of Forensic Science, Aurangabad, and Deputy Director, Groundwater Surveys and Development Agency, Aurangabad, Maharashtra, India for providing all necessary support.

\section{References}

[1] Aher, K. R., and Deshpande, S. M. (2011). Assessment of water quality of the Maniyad Reservoir of Parala Village, district Aurangabad: Suitability for multipurpose usage. International Journal of Recent Trends in Science and Technology, 1(3), 91-95.

[2] Aher, K. R. (2017). Delineation of groundwater quality for drinking and irrigation purposes: a case study of Bori Nala watershed, district Aurangabad, Maharashtra, India. Journal of Applied Geochemistry, 19(3), 321-338.

[3] Aher, K.R and Gaikwad, S.G. (2017). Irrigation groundwater quality based on hydrochemical analysis of Nandgaon block, Nashik district in Maharashtra. International Journal of Advanced Geosciences, 5(1), 1-5. https://doi.org/10.14419/ijag.v5i1.7116.

[4] Aher,K.R. and Dhumal, M.L. (2017). Multivariate Statistical Analyses of Physicochemical Parameters in Groundwater Samples of Borinala Watershed of Aurangabad District, Maharashtra, India. Bulletin of Pure \& Applied Sciences-Geology,36 (1),18-26. https://doi.org/10.5958/23203234.2017.00002.6.

[5] Aher, K. R., Deshpande, S. M., and Varade, A. M. (2019). Groundwater Quality Assessment Studies in Yeola Block of Nashik District, Maharashtra. Journal of Geosciences, 4(1), 11-22.

[6] Aher, K. R., Pathrikar, P. B., Golekar, R. B., Gaikwad, G. D., Borgawkar, A. R. and Kathane, P. V.(2020). Application of Water Quality Index and Multivariate Statistical Analysis in the Hydrogeochemical Assessment of Shallow Groundwater in Part of Purna Basin, Maharashtra, India. Bulletin of Pure \& Applied Sciences-Geology, 39F (2), 239-255.

[7] Aher K.R, Gaikwad, S.G. and Salve P.L. (2020a). Assessing groundwater quality using water quality index in semiarid region of Aurangabad district, central India, International Journal of Advanced Geosciences, 8 (2), 249-258. https://doi.org/10.14419/ijag.v8i2.31139.

[8] Alobaidy, A. H. M. J., Abid, H. S., \& Maulood, B. K. (2010). Application of water quality index for assessment of Dokan lake ecosystem, Kurdistan region, Iraq. Jour. Water Resour. Prot., v.2(09), pp.792. https://doi.org/10.4236/jwarp.2010.29093.

[9] APHA, (2012). Standard methods for the examination of water and wastewater (20thEd.). Washington D.C.: American Public and Health Association. pp. 6-187.

[10] Bidhuri, S., Khan, M.M.A. (2020). Assessment of Ground Water Quality of Central and Southeast Districts of NCT of Delhi. J Geol Soc India 95, 95-103. https://doi.org/10.1007/s12594-020-1390-7. 
[11] Boah, D. K., Twum, S. B., \& Pelig-Ba, K. B. (2015). Mathematical computation of water quality index of Vea dam in upper east region of Ghana. Environ Sci, 3(1), 11-16. https://doi.org/10.12988/es.2015.4116.

[12] Boyacioglu H (2007) Development of a water quality index based on a European classification scheme. Water SA 33(1):101-106. https://doi.org/10.4314/wsa.v33i1.47882.

[13] Boyacioglu, H. (2010). Utilization of the water quality index method as a classification tool. Environ Monit Assess 167, 115-124. https://doi.org/10.1007/s10661-009-1035-1.

[14] Bozdag,A. and Gocmez, G. (2013). Evaluation of groundwater quality in the Cihanbeyli basin, Konya, Central Anatolia, Turkey. Env. Earth. Sci., v. 69, pp. 921-937. https://doi.org/10.1007/s12665-012-1977-4.

[15] Brown RM, McClelland NI, Deininger RA, Tozer RG (1970) Water quality index — do we dare? Water Sew Works 117(10):339-343.

[16] Brown, R.M., McClelland, N.I., Deininger, R.A. and O’Connor, M. F. (1972). A water quality index — crashing the psychological barrier. In: Indicators of environmental quality, Springer, Boston, MA, (pp. 173-182). https://doi.org/10.1007/978-1-4684-2856-8 15.

[17] Bureau of Indian Standards (BIS) (2012) Indian Standard Specification for Drinking Water, (IS-10500-2012). Indian Standards Institution, New Delhi.

[18] Chaterjee, C., \& Raziuddin, M. (2002). Determination of water quality index (WQI) of a degraded river in Asanol Industrial area, Raniganj, Burdwan, West Bengal. Nature Environment and Pollution Technology, 2, 181-189.

[19] CIA (2014). The World Factbook 2014, Central Intelligence Agency (Ed.).

[20] Dangi, K., Kulshreshtha, V. and Dev, P. (2018). Variation trend analysis of rainfall hydrometerological parameter and environmental implications on sitamau watershed, Mandsaur District, MadhyaPradesh, India, Bulletin of Pure \& Applied Sciences-Geology, 37 (2), 186-200. https://doi.org/10.5958/2320-3234.2018.00017.3.

[21] Deshpande S.M, Aher K.R. (2012) Evaluation of groundwater quality and its suitability for drinking and agriculture use in parts of Vaijapur, District Aurangabad, MS, India. Res J Chem Sci 2(1):25-31.

[22] Deshpande, S. M., Aher, R. K., Gaikwad, G. D.,and Aher, K. R. (2020). Groundwater Quality Index of Dheku River Basin of Maharashtra, India: A Mathematical Approach. Bulletin of Pure \& Applied Sciences-Geology,39F (2), 256-263.

[23] Dhumal, M. L., and Aher, K. R. (2019). Time series analysis of Rainfall data and its Geo-environmental inferences on Girja Basin, Aurangabad District of Maharashtra, India. Int. J. Sci. Res. in Mathematical and Statistical Sciences, 6 (2), 272-283.

[24] Diersing and Nancy (2009). Water Quality: Frequently asked questions, Florida Brooks National Marine Sanctuary, Key West, FL.

[25] Horton RK (1965) An index number system for rating water quality. J Water Pollut Control Fed 37(3):300-306

[26] Jagadeeswari, P. B., \& Ramesh, K. (2012). Water quality index for assessment of water quality in South Chennai coastal aquifer, Tamil Nadu, India. International Journal of ChemTech Research, 4(4), 1582-1588.

[27] Jiang, Y. and Yan, J. (2010). Effects of land use on hydrochemistry and contamination of Karst groundwater from Nandong underground river system, China.WaterAir Soil Poll., v. 210, pp. 123-141. https://doi.org/10.1007/s11270-009-0229-z.

[28] Ketata, M., Gueddari, M. and Bouhlila, R. (2012). Use of geographical information system and water quality index to assess groundwater quality in El Khairat deep aquifer (Enfidha, Central East Tunisia). Arabian Jour. Geosci., v.5 (6), pp.1379-1390. https://doi.org/10.1007/s12517-011-0292-9.

[29] Krishan, G., Sharma, L.M., Yadav, B.K. and Ghosh, N.C. (2016) Analysis of Water Level Fluctuations and TDS Variations in the Groundwater at Mewat (Nuh) District, Haryana (India). Curr. World Environ., v.11(2), pp.388. https://doi.org/10.12944/CWE.11.2.06.

[30] Latha, P.S. and Rao, K.N. (2010) Assessment and Spatial Distribution of Quality of Groundwater in Zoneii and III, Greater Visakhapatnam, India using Water Quality Index (WQI) and GIS. Internat. Jour. Environ. Sci., v.1 (2), pp.198-212.

[31] Li, P. (2016) Groundwater quality in western China: challenges and paths forward for groundwater quality research in western China. https://doi.org/10.1007/s12403-016-0210-1.

[32] Mishra P.C, Patel R.K. (2001). Study of pollution load in the drinking water of Rairangpur: a small tribal dominated town of North Orissa. Indian J Environ Ecoplan 5(2):293-298.

[33] Naik S, Purohit K.M. (2001). Studies on water quality of river Brahmani in Sundargarh district, Orissa. Indian J Environ Ecoplan 5(2):397-402.

[34] Papatheodorou G, Demopoulou G, Lambrakis N (2006). A long-term study of temporal hydrochemical data in a shallow lake using multivariate statistical techniques. Ecol Model 193:759-776. https://doi.org/10.1016/j.ecolmodel.2005.09.004.

[35] Ravikumar, P., Mehmood, M. A., \& Somashekar, R. K. (2013). Water quality index to determine the surface water quality of Sankey Tank and Mallathahalli Lake, Bangalore Urban District, Karnataka, India. Applied water science, 3(1), 247-261. https://doi.org/10.1007/s13201-013-0077-2.

[36] Sahu P, Sikdar PK (2008) Hydrochemical framework of the aquifer in and around East Kolkata wetlands, West Bengal. India Environ Geol 55:823-835. https://doi.org/10.1007/s00254-007-1034-x.

[37] Shah, K.A.,and Joshi, G.S. (2017) Evaluation of water quality index for River Sabarmati, Gujarat, India. Appl Water Sci 7, 1349-1358 (2017). https://doi.org/10.1007/s13201-015-0318-7.

[38] Sheikhy, N.T., Ramli, M.F., Aris, A.Z., Sulaiman,W.N.A., Juahir, H. and Fakharian, K. (2014). Identification of the hydrogeochemical processes in groundwater using classic integrated geochemical methods and geostatistical techniques, in Amol-babol plain, Iran. Sci.World Jour., pp. 1-15. https://doi.org/10.1155/2014/419058.

[39] Singh D.F. (1992) Studies on the water quality index of some major rivers of Pune. Maharashtra. Proc Acad Environ Biol. 1(1):61-66.

[40] Sridharan, M. and Nathan, D.S. (2017). Groundwater quality assessment for domestic and agriculture purposes in Puducherry region. App. Water Sci., v. 7(7), pp. 4037-4053. https://doi.org/10.1007/s13201-017-0556-y.

[41] Tiwari T.N and Mishra M.A. (1985). A preliminary assignment of water quality index of major Indian rivers. Indian J Environ Proc 5:276-279.

[42] Tyagi S, Sharma B, Singh P, Dobhal R (2013) Water quality assessment in terms of water quality index. Am J Water Resour 1(3):34-38 https://doi.org/10.12691/ajwr-1-3-3.

[43] UN-Water (2010) Statement on water quality.www.unwater.org. Accessed 12th January 2020.

[44] US EPA (2009). Environmental impact and benefits assessment for final effluent guidelines and standards for the construction and development category. Office of Water, Washington, DC. EPA-821-R-09-012.

[45] Varade, A.M., Yenkie, R., Shende, R. and Kodate, J. (2014). Drinking water quality assessment studies for an urbanized part of the Nagpur District, Central India. Jour. Env. Sci. Engg., v.56 (1), pp.53-64.

[46] Wagh, V.M., Panaskar, D.B., Mukate S.V., Gaikwad, S.K., Muley, A.A. and Varade, A.M. (2018). Health risk assessment of heavy metal contamination in groundwater of Kadava River Basin, Nashik, India. Modeling Earth Sys. Env., https://doi.org/10.1007/s40808-018-0496-z.

[47] WHO (2011) Guidelines for drinking-water quality, World Health Organization, 3rd edn, vol 1. Recommendations. Geneva, Switzerland, pp 515

[48] Yogendra, K. and Puttaiah, E. T. (2008). Determination of water quality index and suitability of an urban waterbody in Shimoga Town, Karnataka. In: Proc. Taal2007: The 12th world lake conference, v.342, p.346.

[49] Zhang, B., Song, X., Zhang, Y., Han, D., Tang, C., Yu, Y. and Ma, Y. (2012). Hydrochemical characteristics and water quality assessment of surface water and groundwater in Songnen plain, Northeast China.Water Res., v. 46(8), pp. 2737-2748. https://doi.org/10.1016/j.watres.2012.02.033. 